Ann. Génét. Sél. anim. I969, 1 (4), 423-438.

\title{
ADRENAL MORPHOLOGY AND HYDROXYSTEROID DEHYDROGENASE ENZYMES IN NORMAL AND INTERSEX GOATS
}

\author{
Parvathi-K. BASRUR and H. KANAGAWA* \\ Department of Biomedical Sciences \\ University of Guelph \\ Guelph, Ontario, Canada
}

SUMMARY

A comparison of the adrenal morphology in 6 intersexes with that of normal adultgoats and kids indicated that the total size of the adrenal in the intersexes was much reduced as compared to that of adults. The intersex goats resembled week-old kids in total size and in cortex to medulla ratio. Histometric analysis on the relative thickness of the outermost cortical zone (zona glomerulosa) and the two inner zones (zona fasciculata and zona reticularis) revealed that the former in normal males occupied more than a third of the total cortical area whereas this zone in the kids and adult females approximated a fifth. The intersexes were in between the adult females and adult males in the relative distribution of their inner adrenal zones.

Histochemical studies on hydroxysteroid dehydrogenase enzymes in the adrenals and the gonads of normal and intersex goats revealed localization of $3 \beta$-hydroxysteroid dehydrogenase in the zona reticularis in male goats and intersexes when androstenediol was used as the substrate whereas the intensity was much lower in the other two zones of intersexes as compared to those of normal goats. The ability of the adrenal enzymes to use pregnenolone as substrate was exhibited by all three cortical zones of all goats even though this reaction was more diffuse in adult goats whereas in intersexes and kids the reaction was localized at the junction of zona glomerulosa and zona fasciculata. The presence of 17 -hydroxysteroid dehydrogenase was not demonstrable using either estradiol or testosterone as substrates in intersexes and normal adult males. Traces of this enzyme was detected in the adrenal cortex of the kids using testosterone as substrate and a similar weak reaction was noticeable with estradiol as substrate in the inner zones of females. The distribution of $3 \beta$-hydroxysteroid dehydrogenase in the Leydig cells was weak in male goats and intersexes when androstenediol was used as the substrate. In similar experiments using pregnenolone as substrate, a weak positive reaction was noted in the Leydig cells of intersexes and in the stroma of adult females but the reaction was negative in adult males and kids. As in their adrenals, the presence of 17 -hydroxysteroid dehydrogenase was not detectable in the testes either with testosterone or estradiol as substrates.

The marked hypoplasia and cellular damage affecting the adrenal cortex of intersexes and their closer resemblance to the kids in the distribution of hydroxysteroid dehydrogenase enzymes are considered to be indicative of a generalized interference with their steroid hormone-producing cells.

(*) National Research Council Postdoctoral Fellow. 


\section{INTRODUCTION}

The characteristic features of intersex goats have been noted to be female genotype, male gonads and varying degrees of intersexual modifications of the internal and external genitalia (BASRUR and CoUBRough, I964; BASRuR and KANAGAWA, I968; HAMERTON et al., I969). This condition in goats, in certain aspects, resemble the congenital virilization noted in other domestic animals (GARM, r949) and humans (ZANDER and HenNing, I963). Among domestic animals the freemartin condition in cattle has been attributed to intra-uterine virilization of the female gonad by exogenous sex hormone elaborated by the developing testes of the male co-twin (LILIIE, I9I7). The transfer of male hormone to the female gonad is assumed to be facilitated by the vascular anastomosis which also result in chimerism in the hematopoietic and gonadal tissues of both twins. In goats, intersexuality is not generally associated with twinning or chimerism although recently chimerism has been demonstrated in a few female goats born twin to male goats (PADEH, I965; ILBERY and WILLIAMS, I967; SolLER et al, I969; HAMERTON, et al., I969; BASRUR and KANAGAWA, I969). A possible source of virilizing influence on the female fetus is the adrenal which is the only non-gonadal gland known to produce sex hormones in mammals ( $Z_{\mathrm{AN}}$ DER and HENNING, I963). In humans certain defects in adrenal function have been implicated in the virilization of females (OvERzIER, I963; ZANDER and HENNING, I963).

In the present investigation the adrenals of a group of intersex goats were compared with those of normal goats in order to test whether or not a hyperactivity of this gland similar to that noted in the adreno-genital syndrome in humans (CHESTER-Jones, r957) is associated with the caprine intersexuality. A further impetus to this investigation was a report by WIDMAIER (I959) that adrenal tissue frequently occurs in the head of the epididymis in normal and intersex polled goats.

\section{MATERIALS AND METHODS}

The goats used in this study belonged to Saanen and Nubian breeds obtained from the Ontario Veterinary College Research farm and from the goat breeders at different parts of Southern Ontario. The normal goats included 7 males (4 Saanens and 3 Nubians), 4 females (3 Saanens and 1 Nubian), 5 male kids (4 one-week old Saanens and a one-week old Nubian) and 3 female kids ( 2 one-week old Saanens and a one month old Nubian). Of the 6 intersexes included in this study, 4 were Saanens and 2 were Nubians. One Nubian and two Saanens were under a year old, while the others ranged in age from 18 to 30 months. The adult goats were polled and the kids, as far as one could judge from the nature of the thickened skin noted in the place of the horns, were also polled.

Adrenal glands and gonads were removed immediately after electrocution of the animals and pieces of tissues were fixed in Zenker's fluid and 10 per cent neutral buffered formalin for histologic preparations.

For the study of hydroxysteroid dehydrogenase enzymes, pieces of tissues were cut into approximately $5.0 \mathrm{~mm}^{3}$ blocks and were first fixed in neutral buffered formalin-calcium chilled on dry ice. The specimens were washed with cold double distilled water and sections, approximately $10 \mu$ thick, were cut in the cryostat. The cryostat sections were mounted directly on coverslip prior to drying at room temperature for about 5 minutes. The sections were treated with $0.1 \mathrm{M}$ phosphate buffer ( $\mathrm{pH} 7.4$ ) for 10 minutes before incubation, to remove soluble endogenous substrates. To demonstrate the hydroxysteroid dehydrogenase activity, sections were incubated for one hour at $37^{\circ} \mathrm{C}$ in a medium containing $4.0 \mathrm{ml}$ of $0.1 \mathrm{M}$ phosphate buffer solution, 
$0.8 \mathrm{ml}$ aqueous solution of 0.3 percent nicotinamide adenine dinucleotide (NAD), $1 \mathrm{ml}$ of 0.1 percent aqueous nitro-blue tetrazolium (NBT), and a $0.5 \mathrm{ml}$ solution of the steroid substrate dissolved in dimethyl formamide (DMF). The four steroids used as substrates in this study were $\Delta^{5}$-Androsten-3 $\beta$-17 $\beta$-diol (androstenediol), 17 $\beta$-Estradiol ( $\beta$-estradiol), $\Delta^{5}$-Pregnen-3 $\beta$ ol-20-one (pregnenolone) and $\Delta^{4}$ - Androsten-17 $\beta$-ol-3-one (testosterone) at a final concentration of $0.5 \mathrm{mM}$.

Control sections were handled in the same manner and incubated in a medium lacking only the steroid substrate.

Following incubation the coverslips with the sections were rinsed in water prior to inverting on a drop of farrant's mounting medium on a precleaned slide. Sections were examined immediately after mounting, under a Ziess Photomicroscope and the reactions were subjectively recorded as negative $(-)$ for total absence of staining reaction, weak positive ( \pm ) for trace and positives $(+$ to ++++$)$ to indicate varying degrees of intensity of formazan deposits. Photomicrographs were taken within $\mathbf{3 0}$ minutes after staining for the detection of enzyme reactions.

Histometric studies on adrenals were carried out in two ways: The histologic sections were projected at a fixed magnification in a Leitz Focomat enlarger on Kodalith ortho-type 3 film which was processed in the routine manner to get the negative image. The total width of the entire gland, the areas occupied by the cortex and the medulla and the width of the cortical zones were measured in arbitrary units from each negative. The cortex was divided into the outer zone (zona glomerulosa) alone, and the two inner zones (zona fasciculata and reticularis) together. Similar sections were also measured using an occular micrometer in a $\times 10$ eye piece, with a Leitz orthoplan microscope. Since the relative distribution of widths by the two methods were remarkably similar, the mean values for each group was estimated using the information obtained from both sets of measurements.

\section{RESULTS}

\section{Adrenal morphology}

The adrenal glands of the intersexes (fig. I) were strikingly different from those of normal adult goats of comparable age in total size and in the width of the cortical zones, but resembled more closely those of one-week old kids (fig. 2). The adult female goats, on the other hand differed from adult males in general appearance and in the relative widths of their cortex and medulla (fig. 3 and 4). The cortical region in adult female goats was wider than that noted in the other groups of goats included in this investigation (Table $\mathrm{I}$ ).

TABLE I

Mean thickness in arbitrary units of adrenal cortex and medulla in normal and intersex goats

\begin{tabular}{|c|c|c|c|c|c|c|}
\hline \multirow{2}{*}{\multicolumn{2}{|c|}{ Animals }} & & & \multicolumn{3}{|c|}{ Thickness in Arbitrary Units } \\
\hline & & & & Cortex & Medulla & $\begin{array}{l}\text { Cortex/ } \\
\text { Medulla }\end{array}$ \\
\hline Adult males . . & & . & . & $5^{2 \cdot 3 I}$ & $35.8 \mathrm{I}$ & 0.68 \\
\hline Adult females. & . & . & . . & 60.1 & 30.90 & $0.5^{I}$ \\
\hline Old intersexes & . & . & . . & $39 \cdot 30$ & $60.7 \mathrm{I}$ & I.54 \\
\hline Young intersexes & . & $\cdot$ & . . & 37.80 & 58.10 & 1.53 \\
\hline Male kids . . . & . & . & . . & $4^{0.91}$ & 52.10 & $I .24$ \\
\hline Female kids . . & . & . & . . & 38.12 & $53.8 \mathrm{I}$ & I. $4 \mathrm{I}$ \\
\hline
\end{tabular}

The older intersex goats exhibited some degree of tissue damage and indications of cell replacement in the zona glomerulosa (fig. 5-8). Mitotic figures at this region in intersexes were more frequent than in normal goats (fig. 5) al- 

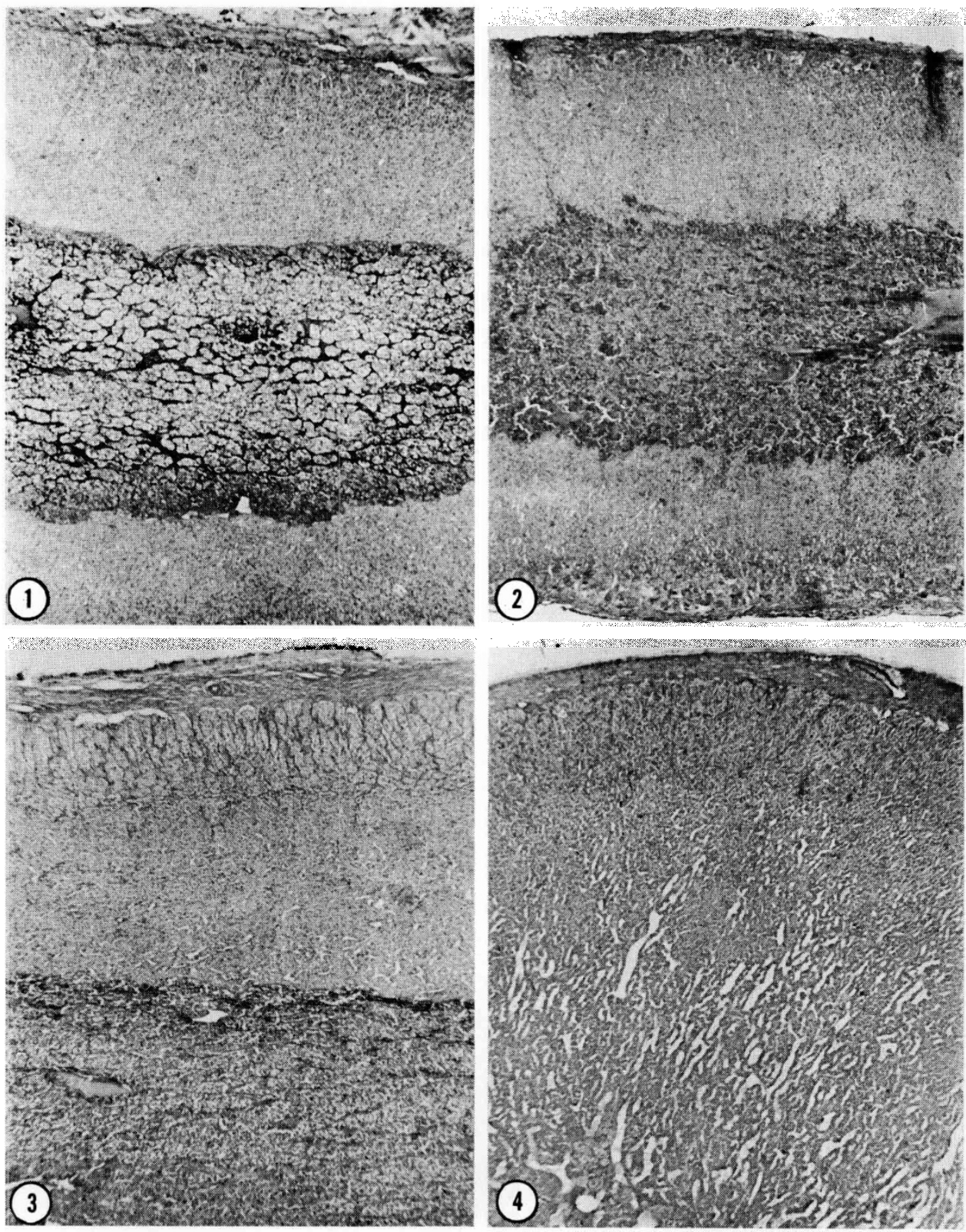

PLATE I

FIG. I-4. - Sections of the adrenal glands from normal and intersex goats. $\times$ roo.

FIG. I. - A section of the adrenal from a two year old intersex goat showing the width of the medulla and the cortex on both sides.

FIG. 2. - A similar section from a week-old kid.

Fig. 3. - A section from a two year old male goat. Note that only part of the medulla was included in the photomicrograph taken at the same magnification as figures $I$ and 2 .

FIG. 4. - A section of the adrenal from a two year old female goat.

Note that the cortical region occupies almost the whole area in this micrograph. 
though actual width of this appeared to be much narrower (fig. 6) than in normal adults. The cortical cells were often noted to penetrate the capsular area in adults and intersexes although in older intersex goats the islands of ectopic cortical tissue was noted to be infiltrated by macrophage-like cells (fig. 7) or extremely vacuolated (fig. 8). In one intersex the glomerulosa cells at several regions were noted to be replaced by groups of cross striated muscle cells (fig. 9 and Io) which were not detected in normal adult goats or kids.

Histometric studies on the adrenals of normal adults, kids and intersexes indicated that the cortex to medulla ratio is reversed in the intersexes from that noted in normal adults (Table I) and that it approximated the ratio of the kids. Analysis of the relative thickness of the zona glomerulosa and the two inner zones (zona fasciculata and zona reticularis) showed that the former in normal females and kids occupied approximately a fifth of the total cortical area (Table 2) whereas

TABLE 2

Relative thickness of the inner zones of adrenal cortex of normal and intersex goats

\begin{tabular}{|c|c|c|c|c|c|}
\hline \multirow{2}{*}{ Animals } & & & & \multicolumn{2}{|c|}{ Relative thickness } \\
\hline & & & & Glomerulosa & $\begin{array}{l}\text { Fasciculata } \\
\text { et Reticularis }\end{array}$ \\
\hline $\begin{array}{l}\text { Adult females } \\
\text { Adult males. } \\
\text { Old intersexes . } \\
\text { Young intersexes } \\
\text { Male kids . . } \\
\text { Female kids . . }\end{array}$ & . & $\begin{array}{ll}\cdot & \cdot \\
\cdot & . \\
\cdot & . \\
\cdot & . \\
\cdot & . \\
. & .\end{array}$ & $\begin{array}{ll}\cdot & \text {. } \\
\cdot & \text {. } \\
\cdot & \text {. } \\
\cdot & \text {. } \\
\cdot & \text {. }\end{array}$ & $\begin{array}{l}20.52 \\
30.64 \\
24.13 \\
23.66 \\
19.95 \\
18.25\end{array}$ & $\begin{array}{l}79 \cdot 4^{8} \\
69 \cdot 36 \\
75.87 \\
76.34 \\
80.05 \\
81.75\end{array}$ \\
\hline
\end{tabular}

this zone in the adult males extended over a third of the cortex. The glomerulosa zone in young and old intersex goats were of intermediary proportions reaching approximately a fourth of the total adrenal cortex.

One of the interesting observations in the present investigation is that the proportion of the inner two zones as well as the total cortical area was greater in female goats than in normal male goats (fig. 3 and 4). All intersexes exhibited marked hypoplasia of the adrenal cortex as did their gonads which in a majority of cases was considerably smaller than those of normal adult goats of comparable age.

\section{PLANCHE, I}

Fig. I à 4. - Coupes dans la glande surrénale de chèvres normales et intersexuées. $\times$ roo. Fig. I. - Coupe de la surrénale d'une chèvre intersexuée de deux ans montrant la largeur de la medulla et le cortex des deux côtés.

FIG. 2. - Ia même coupe chez un chevreau d'une semaine.

Fig. 3. - Coupe chez un bouc de deux ans. Notez que seule une partie de la medulla est incluse dans la photo prise avec le même agrandissement que les figures I et 2.

Fig. 4. - Coupe de la surrénale d'une chèvre femelle âgée de deux ans.

Notez que la région corticale occupe presque toute la superficie de la photo. 


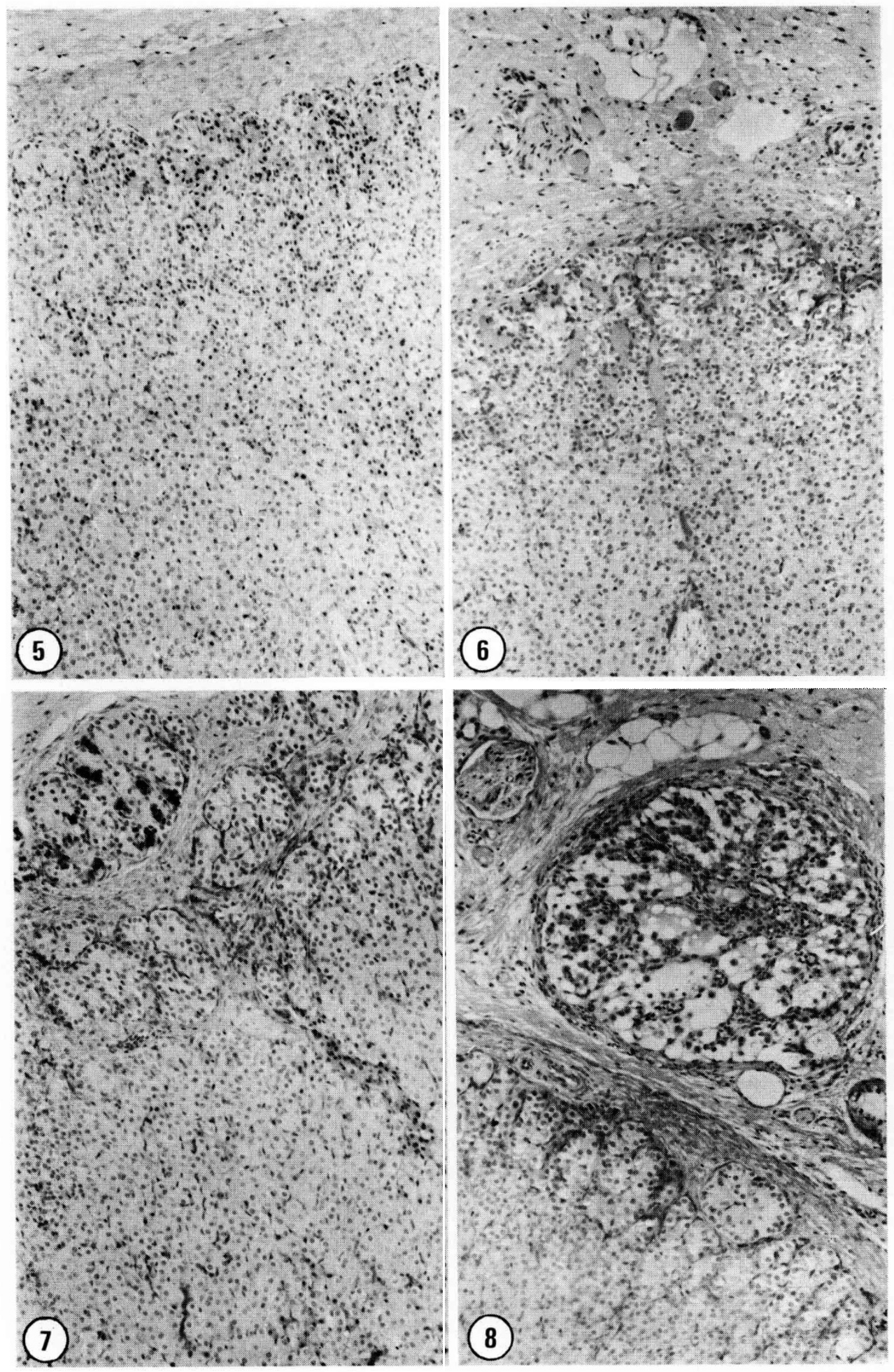



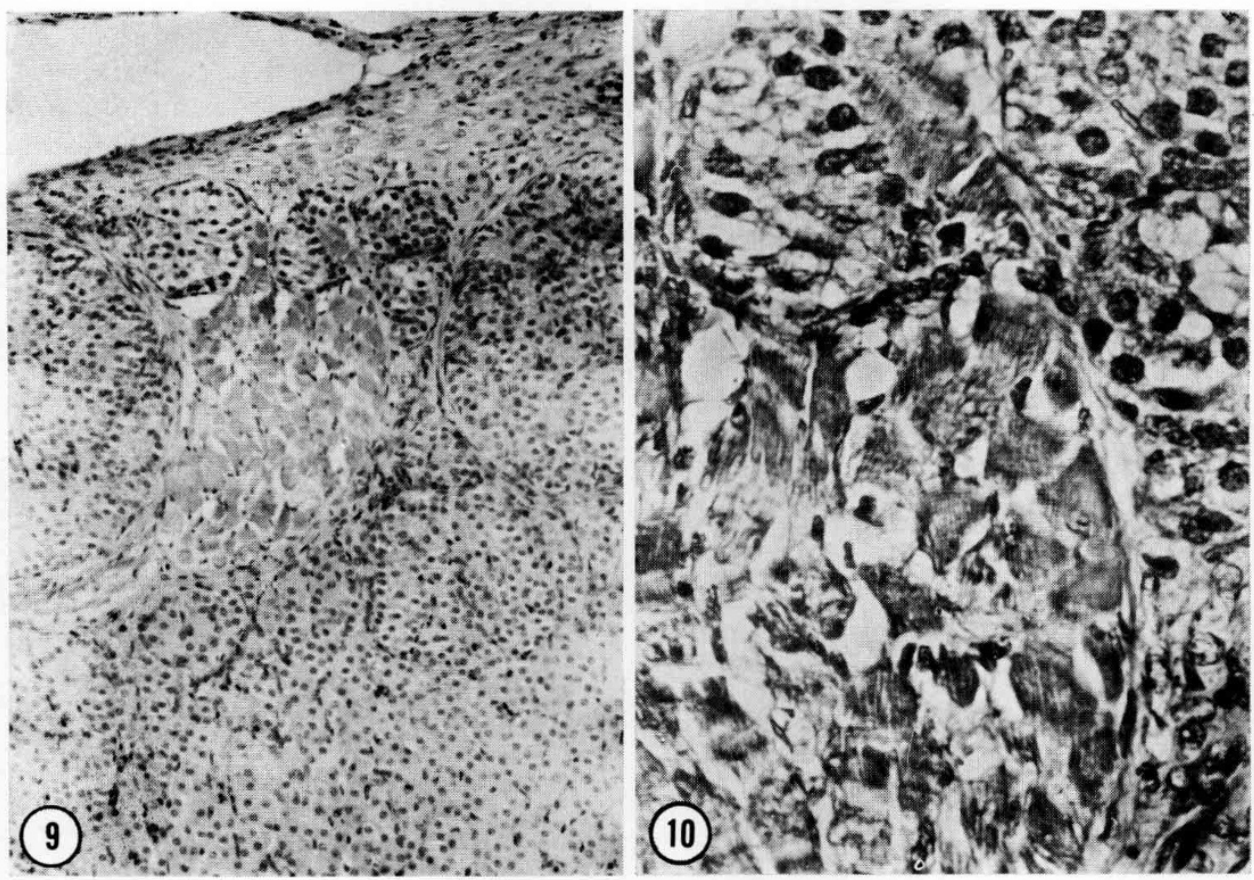

\section{PLATE III}

FrG. 9 and Io. - Adrenal cortical region from a 30-month-old intersex goat showing replacement of glomerulosa cells with a bundle of thin cross striated muscle cells. Fig. $9, \times 250$; Fig. Io, $\times 500$.

\section{PLANCHE III}

FIG. 9 et ro. - Région cortico-surrénale d'une chèvre intersexuée de 30 mois montrant le remplacement des cellules glomérulaires par un faisceau de fines cellules musculaires striées entrecroisées. Fig. 9, $\times 250$. Fig. Io, $\times 500$.

\section{PLATE II}

FIG. 5-8. - Sections of adrenal cortex from intersex goats showing varying degrees of cellular damage. $\quad \times 250$. FIG. 5. - An I8-months-old intersex goat showing high mitotic activity in the glomerulosa zone.

FIG. 6. - A 24-months-old intersex goat showing a much reduced zona glomerulosa.

FiG. 7. - A 30-months-old intersex goat exhibiting infiltration of macrophage-like cells in the ectopic aggregates of adrenocortical cells.

FIG. 8. - An island of glomerulosa-like tissue in the capsular region of a 30-months-old intersex goat. Note the extreme vacuolation in the cells.

\section{PLANCHE II}

FIG. 5 à 8 . - Coupe dans le cortex surrénalien de chèvres intersexuées montrant différents degrés d'altération cellulaire. $\times 250$.

FIG. 5. - Chèvre intersexuée de 18 mois montrant une activité mitotique élevée dans la zone glomérulaire.

FIG. 6. - Chèvre intersexuée de 24 mois présentant une zone glomérulaire très réduite.

Fig. 7. - Chèvre intersexuée de 30 mois présentant une infiltration de cellules semblables à des macrophages dans les aggrégats ectopiques des cellules adrénocorticales.

FIG. 8. - Ilot de tissu de type glomérulaire dans la région capsulaire d'une chèvre intersexuée de 30 mois. Notez l'extrême vacuolisation des cellules. 


\section{Hydroxysteroid dehydrogenase enzymes}

The distribution of formazan deposits in the adrenal sections from all specimens was confined to the cortical region. The pattern of localization of the stain in these sections varied with the steroid substrate used in the incubation medium (Table 3). Using pregnenolone as substrates, the localization of reaction in intersex

TABLE 3

The distribution of $\Delta^{5}-3 \beta$ and $\mathrm{I} 7 \beta$-hydroxysteroid desydrogenase enzymes in the adrenal cortex of goats

\begin{tabular}{|c|c|c|c|c|c|}
\hline \multirow{2}{*}{$\begin{array}{l}\text { Type of animals } \\
\text { used }\end{array}$} & \multirow{2}{*}{ Tissue } & \multicolumn{4}{|c|}{ Substrates used } \\
\hline & & Test. & Pregn. & Andr. & Estr. \\
\hline Adult males (7) & $\begin{array}{l}\text { Glomerulosa } \\
\text { Fasciculata } \\
\text { Reticularis }\end{array}$ & $\overline{-}$ & $\begin{array}{l}+ \\
++ \\
++\end{array}$ & $\begin{array}{c}+ \\
++ \\
+++\end{array}$ & 二 \\
\hline Adult females (4) & $\begin{array}{l}\text { Glomerulosa } \\
\text { Fasciculata } \\
\text { Reticularis }\end{array}$ & E & $\begin{array}{l}+ \\
++ \\
++\end{array}$ & $\begin{array}{l}+ \\
+++ \\
+++\end{array}$ & $\begin{array}{l}\overline{+} \\
+ \\
+\end{array}$ \\
\hline Male kids (5) & $\begin{array}{l}\text { Glomerulosa } \\
\text { Fasciculata } \\
\text { Reticularis }\end{array}$ & $\begin{array}{l} \pm \\
\pm \\
\pm\end{array}$ & $\begin{array}{l}+++ \\
++ \\
+++\end{array}$ & $\begin{array}{l}++ \\
++ \\
++\end{array}$ & - \\
\hline Female kids (3) & $\begin{array}{l}\text { Glomerulosa } \\
\text { Fasciculata } \\
\text { Reticularis }\end{array}$ & $\begin{array}{l} \pm \\
\pm \\
+\end{array}$ & $\begin{array}{c}+++ \\
++ \\
+++\end{array}$ & $\begin{array}{l}++ \\
++ \\
+++\end{array}$ & $\begin{array}{l}- \\
+ \\
+\end{array}$ \\
\hline Intersexes (6) & $\begin{array}{l}\text { Glomerulosa } \\
\text { Fasciculata } \\
\text { Reticularis }\end{array}$ & E & $\begin{array}{c}++ \\
+++ \\
++\end{array}$ & $\begin{array}{c}+ \\
+ \\
+++\end{array}$ & E \\
\hline
\end{tabular}

(*) Numbers shown in the brackets indicate the number of animals used.

Test. Testosterone ( $\Delta^{4}$-Androsten-173-ol-3-one).

Pregn. Pregnenolone ( $\Delta^{5}$-Pregnen-3 $\beta$-ol-2o-one).

Andr. Androstenediol ( $\Delta^{5}$-Androsten-3 $\beta$-1 $7 \beta$-diol).

Estr. $\quad$ I $\beta$-Estradiol.

\section{PI,ATF: IV}

FIG. II-I4. - Distribution of formazan deposits indicative of $3 \beta$-hydroxysteroid dehydrogenase activity in adrenal sections of goats, incubated with pregnenolone in the enzyme reaction system. $\times 250$.

FIG. II. - $A$ section of the adrenal from a normal male goat.

FIG. I2. - A similar section from an intersex goat of comparable age.

FIG. I3. - A section of adrenal from a normal female goat.

FIG. I4. - A section of adrenal from a week-old male kid.

PLANCHE IV

FIG. I I à I 4. - Répartition des dépôts de formazan indicateurs de l'activité de la 3 -hydroxystérö̈de deshydrogénase dans des coupes surrénaliennes de chèvres avec incubation de pregnenolone dans le système réactif enzymatique. $\times 250$.

Fig. Ir. - Coupe de la surrénale d'un bouc normal.

Fig. I2. - Même coupe chez une chèvre intersexuée de même âge.

Fig. I3. - Coupe de la surrénale d'une chèvre femelle normale.

FIg. 14. - Coupe de la surrénale d'un chevreau d'une semaine. 

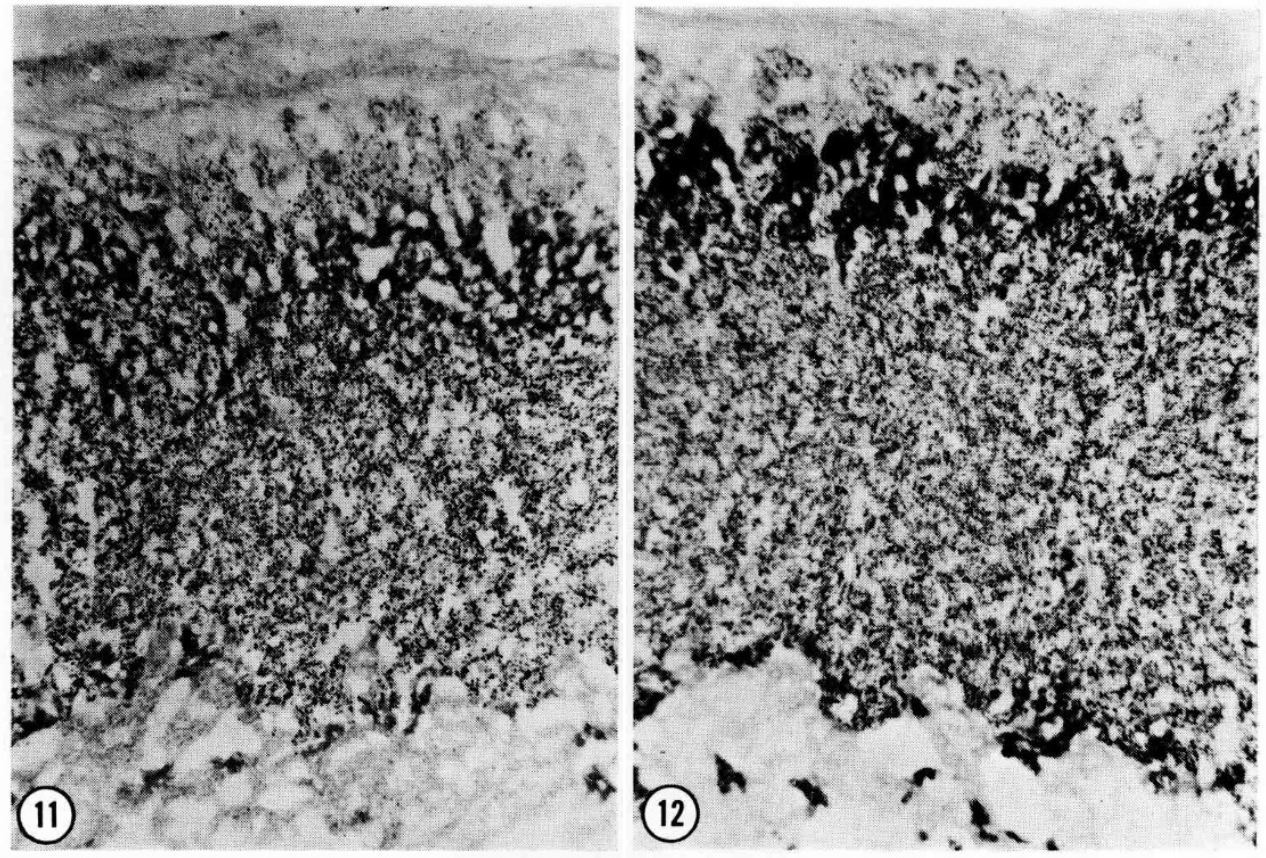

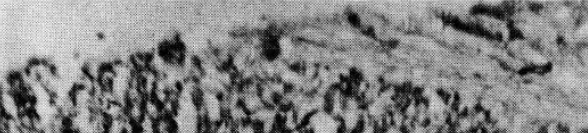

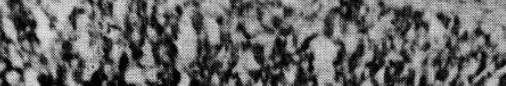

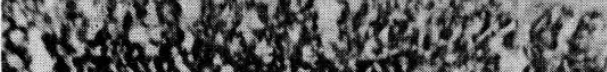
Q.1. If

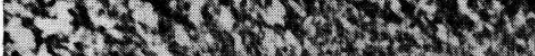

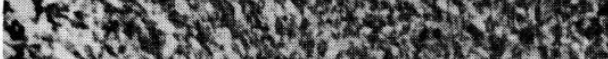

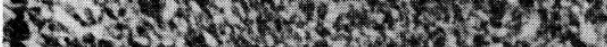
- 4 th $x$.

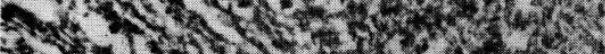

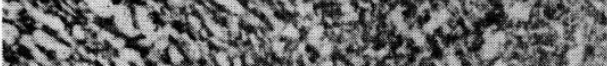
$6 x^{3}$.

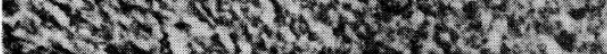

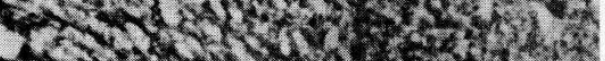

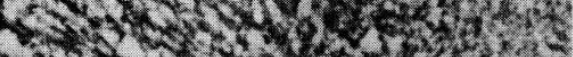

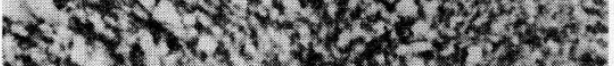
(1) 2.3.3.

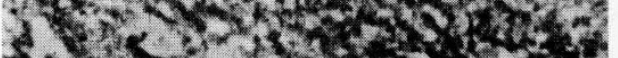

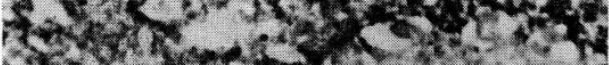

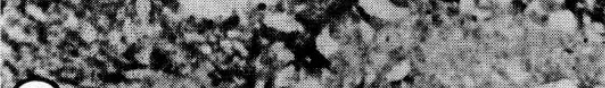

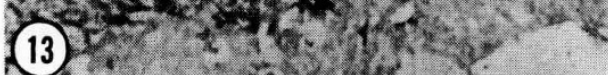

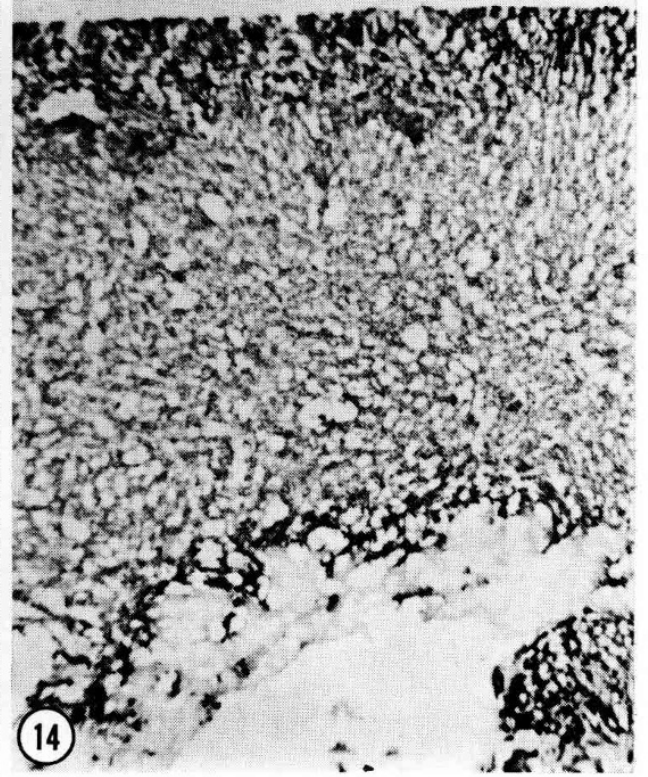


adrenals was more intense in the junction between zona glomerulosa and zona fasciculata whereas in similar experiments with normal adult adrenals the enzyme reaction was more generalized over the entire cortex (fig. II-r3). Adrenals of the kids exhibited relatively strong reaction in the glomerulosa and at the reticularis side of the corticomedullary junction (fig. I4). In sections incubated
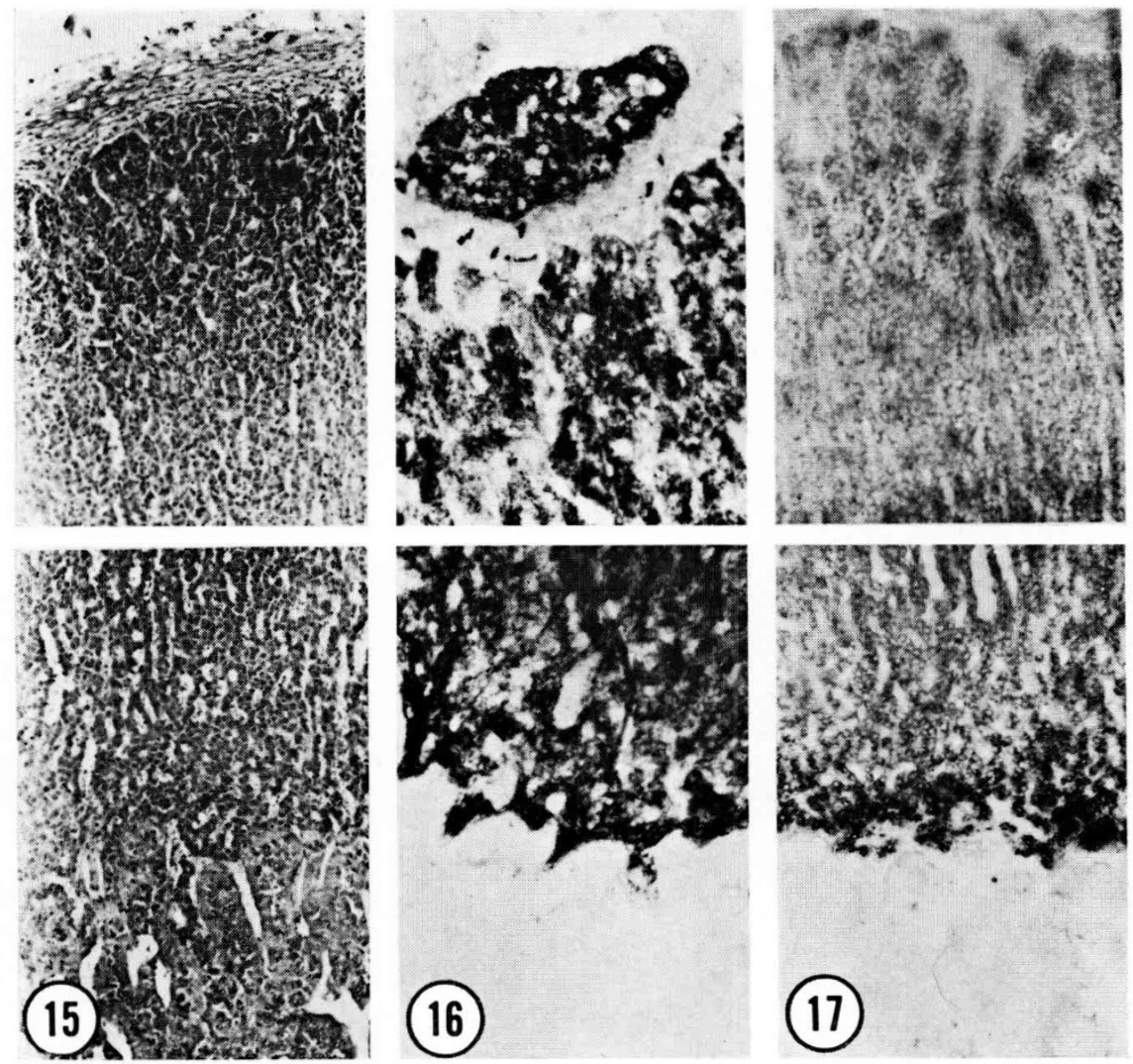

PLATE V

FIG. I5. - A section of the adrenal gland from a normal adult male goat showing the cortex (top) and the medulla (bottom). $H$ and $E . \times$ I5o.

FIG. I6. - A similar section from adult male goat stained for the presence of hydroxysteroid dehydrogenase using androstenediol as substrate. Note that the reaction is confined to the cortical region. $\times 150$.

FIG. 17. - A section from an intersex goat of comparable age. Note that the reaction is intense in the reticularis.

PLANCHE V

FIG. I 5. - Coupe de la surrénale d'un bouc adulte normal : le cortex (en haut) et la medulla (en bas). $\times 150$.

FIG. I6. - Coupe semblable chez un bouc adulte coloré pour rechercher la présence de l'hydroxystéroïde deshydrogénase avec l'androstenediol comme substrat. Notez que la réaction est limitée à la région corticale. $\times$ r5o.

FIG. I7. - Coupe chez un intersexué d'àge comparable. Notez l'intensité de la réaction dans la zone réticulaire. 
with androstenediol intense staining reaction was noted in the inner two zones of adult males whereas in intersexes of comparable age the reactive zone was much narrower and more towards the medulla (fig. I5-I7). The adrenal sections from female goats and the kids showed a moderate reaction throughout the cortex when androstenediol was used as substrate (fig. I8 and I9).
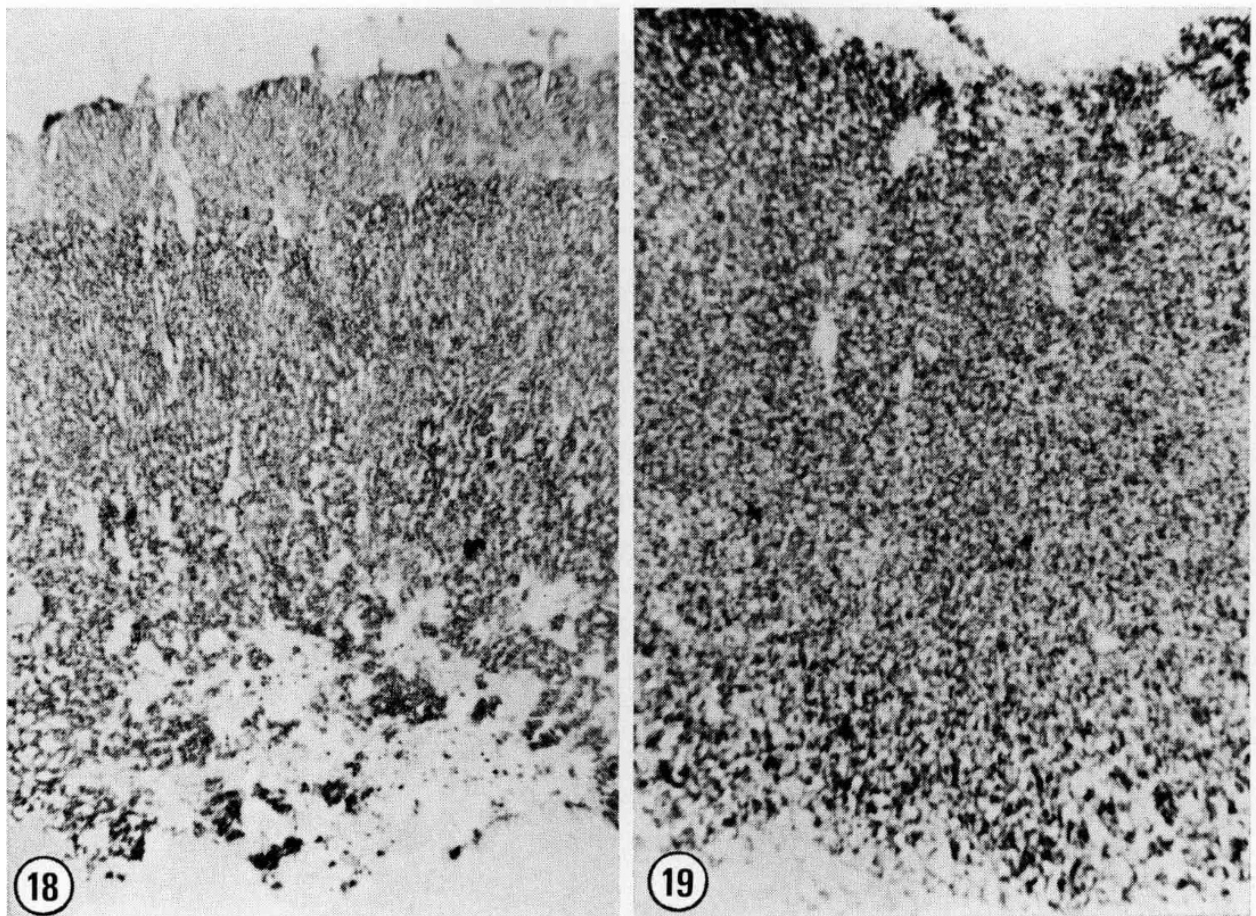

PLATE VI

FIG. 18 and I9. - Adrenal sections from a week-old male kid (Fig. I8) and a 30-month-old normal female (Fig. 19), incubated with androstenediol. Note that the stain reaction is diffuse. $\times 250$.

PIANCHE VI

FIG. 18 et r9. - Coupe dans la surrénale d'un chevreau mâle d'une semaine (Fig. I 8 ) et d'une femelle normale âgée de 30 mois (Fig. 19) incubée avec androstenediol. Notez que la réaction de coloration est diffuse. $\times 250$.

No appreciable enzyme reaction was noted in experiments using testosterone or estradiol as substrates. Control sections incubated with medium lacking in substrates also revealed negative reactions.

The staining reaction was much less intense in the gonadal sections incubated with the various steroid substrates (Table 4). A weak positive reaction in the interstitial regions of adult males and intersexes was noted when androstene diol was used as substrate while with the other substrates the staining reaction was generally negative. 
TABLE 4

The distribution of 5-3 $\beta$ - and $\mathbf{1} 7 \beta$-hydroxysteroid deshydrogenase in the gonads of normal and intersex goats

\begin{tabular}{|c|c|c|c|c|c|}
\hline \multirow{2}{*}{ Animals* } & \multirow{2}{*}{ Tissue } & \multicolumn{4}{|c|}{ Substrates used } \\
\hline & & Test. & Pregn. & Andr. & Estr. \\
\hline $\begin{array}{l}\text { Adult males } \\
(7)\end{array}$ & $\begin{array}{l}\text { Sem. tubules } \\
\text { Leydig cells }\end{array}$ & - & - & $\begin{array}{l}+ \\
++\end{array}$ & - \\
\hline $\begin{array}{c}\text { Adult females } \\
\text { (4) }\end{array}$ & $\begin{array}{l}\text { Follicles } \\
\text { Stroma }\end{array}$ & $\begin{array}{l} \pm \\
\pm\end{array}$ & $\overline{+}$ & 二 & $\overline{+}$ \\
\hline $\begin{array}{l}\text { Male kids } \\
\quad \text { (5) }\end{array}$ & $\begin{array}{l}\text { Sem. tubules } \\
\text { Leydig cells }\end{array}$ & \pm & - & \pm & - \\
\hline $\begin{array}{l}\text { Female kids } \\
\text { (3) }\end{array}$ & $\begin{array}{l}\text { Follicles } \\
\text { Stroma }\end{array}$ & - & - & \pm & $\overline{+}$ \\
\hline $\begin{array}{l}\text { Old intersexes } \\
(4)\end{array}$ & $\begin{array}{l}\text { Sem. tubules } \\
\text { Leydig cells }\end{array}$ & - & $\overline{+}$ & $\overline{++}$ & - \\
\hline $\begin{array}{l}\text { Young intersexes } \\
(2)\end{array}$ & $\begin{array}{l}\text { Sem. tubules } \\
\text { Leydig cells }\end{array}$ & - & $\overline{+}$ & $\overline{++}$ & 二 \\
\hline
\end{tabular}

(*) Numbers shown in brackets indicate the number of animals examined.

Test : Testosterone ( $\Delta 4$-Androsten- $I 7 \beta$-ol-one)

Pregn : Pregnenolone ( $\Delta 5$-Pregnen-3 $\beta$-ol-2o-one).

Andr. : Androstenediol ( $\Delta 4$-Androsten- $3 \beta-I 7 \beta$-diol).

Estr. : $17 \beta$-Estradiol.

\section{DISCUSSION}

Defective adrenal function has been known to cause virilization in cattle (GARM, I949) and in man (ZANDER and HenNING, I963). In some of these cases a hyperactivity of the adrenal gland associated with enlarged cortical zone has been demonstrated (GARM, I949; ChESTER-JONES, I957). WIDMAIER (I959) had reported the presence of islands of adrenal tissue in the epididymis of intersex goats and polled normal goats which were assumed to be carriers of this affliction. Our studies have shown that the total adrenal size in the intersexes are much reduced from that of normal adults and that they resemble one-week old kids in this regard. The relative thickness of the different cortical zones and the degenerative changes noted in the glomerulosa zones of the older intersexes suggest that the adrenal cortex in these goats exhibit marked hypoplasia as do their gonads both of which have similar endocrine functions and embryological origin (OHNo, I967).

In striking contrast to the volume of literature currently available on the cytogenetics of intersex goats, information is rather scanty on the steroid hormone make-up and the pattern of distribution of key enzymes involved in the biosyn- 
thesis of steroids in these animals. This is especially more striking since steroid hormones were first implicated in the induction of congenital and experimental intersexuality in a variety of mammals (LILLIE, I9I7; HUGHES, I929; JoST, I955, I967; OverziER, I963). Recently, ShORT et al., (I968) reported an approximately 4 -fold increase in testosterone and a 5 -fold reduction in androstenedione in the descended testis of an intersex goat, as compared with the normal. These steroid hormones were almost undetectable in the undescended testis (SHORT et al., I968). This trend was also noted in the later studies involving 6 intersex goats (HAMERTON, et al., I969) although there appeared to be considerable variation between each intersex. The concentrations of testosterone detected in the testicular homogenate and in the spermatic vein blood were consistently higher than in the plasma suggesting that these intersexes were actively engaged in steroidogenesis and that the main source of testosterone production in these goats were testes. In our study, the distribution of some of the enzymes involved in steroid biosynthesis were used as indicators for their activity in vivo. The enzyme $\Delta^{5}-3 \beta$-ol-hydroxysteroid dehydrogenase which oxidizes the $\Delta^{5}-3 \beta$-hydroxyl group of steroid to $\Delta^{4}-3$ ketone group (SAmUELS et al., I95I) has been' demonstrated histochemically using NAD as a co-factor (DAwson et al., I96I) and various steroids as substrates in order to demonstrate specific stages in the conversion of steroid molecules (ALLEN, I960; BAILIIE and GRIFFITHS, I964 $a, b$ and r965; DAvies et al., I966; BAILLIE et al., I964).

The direct precursor of biologically active steroids $\Delta^{5}$-pregnenolone is converted to progesterone through the enzyme system $\Delta^{5}-3 \beta$-ol-hydroxysteroid dehydrogenase. This enzyme which has been demonstrated in gonads and adrenals (WATtenberg, I958; KoIde and Mitsude, I965; Davies et al., I966; BailIIE et al., I965; BAYER and SAMULis, I956; BRANDEAU et al., I967) has now been shown to be composed of 2 enzymes (EwALD et al., I964; KoRITz, I964), 3 $\beta$ hydroxysteroid dehydrogenase localized in the microsome fraction of the cells and the $\Delta^{5}-\Delta^{4}$-isomerase, located in the soluble fraction (BLANCHETTE, I966). The distribution of $3 \beta$-hydroxysteroid dehydrogenase is known to exhibit great species variation (MAEIR, I965) and response to hormonal stimulation (BRANDEAU et al., I967; RUBIN et al., I963; SchOR and GLICK, r967).

Our histochemical studies on the adrenal glands of normal goats and intersexes have revealed that the enzyme $3 \beta$-hydroxysteroid dehydrogenase is present in the adrenal cortex of all goats while the intensity of activity varied between intersexes and normal adults. The presence of this enzyme indicates that the initial steps in the biogenesis of corticosteroids involving the formation of progesterone from pregnenolone takes place in goat adrenals as in other mammals (ALLEN, I960; RUBIN et al., I963). The intensity of this reaction was greater towards the periphery of the adrenal cortex in intersexes and kids as compared to adults. The significance of this difference between intersexes and normal goats is not known although this reaction, superficially at least, resembles the pattern exhibited by the adrenal virilizing tumors in humans (RuBIN, I963). It is also conceivable that the intersex adrenals maintain a hormonally " immature " state comparable to those of the kids. The experiments using androstene diol as substrates seem to suggest that the production of androgenic steroids 
may be taking place in intersexes and normal male adrenals although the restricted reaction zone in the former as compared to the normal adult males would indicate a reduced activity.

The distribution of $3 \beta$-hydroxysteroid dehydrogenase in the mammalian testes has been shown to vary greatly. In primate testes this enzyme has never been detected histochemically although strong activity has been demonstrated in the Leydig cells of cat, bat and rats (MAEIR, I965). It would appear that goat testes resemble the primate testis in regard to the histochemical detectability of $3 \beta$-hydroxysteroid dehydrogenase.

The morphology and hydroxysteroid dehydrogenase activity of the adrenal cortex in intersex goats is indicative of hypoplasia and interrupted hormonal activity. It would appear that the distribution and function of the adreno-cortical cells are influenced by the polled genes which in homozygous state affect their gonadal counterparts and cause intersexual modifications in genetic females.

$$
\text { Reçu pour publication en janvier } 1969 .
$$

\title{
RÉSUMÉ
}

\author{
MORPHOLOGIE DE LA SURRFNALE ET OBSERVATIONS \\ CONCERNANT LES HYDROXYSTÉROÏDES DÉHYDROGÉNASES \\ CHEZ LES CHÈVRES NORMALES ET LES CHÈVRES INTERSEXUÉES
}

A la suite d'une comparaison de la morphologie de la surrénale chez 6 intersexuées avec celle de chèvres normales adultes et de chevreaux, on a constaté que la taille totale de la surrénale des intersexuées est beaucoup plus réduite que celle des adultes. La taille totale de la surrénale des intersexuées et la proportion cortex médullo-surrénale sont proches de ceux des chevreaux d'une semaine. L'analyse histométrique de l'épaisseur relative de la zone corticale la plus externe (zone glomérulaire et des 2 zones internes (zones fasciculée et réticulée)) montre que la zone glomérulaire des mâles normaux occupe plus d'1 /3 de l'ensemble de la zone corticale, tandis que cette zone chez les chevreaux et les femelles adultes occupe approximativement $1 / 5$.

La proportion relative des 2 zones internes des intersexuées se situe entre celle des femelles adultes et celle des mâles adultes.

Les études histochimiques des hydroxystéroïdes déhydrogénases dans les surrénales et gonades des chèvres normales et intersexuées révèlent que la $3 \beta$-hydroxystéroïde déhydrogénase existe dans la zone réticulée des mâles normaux et des intersexuées quand on utilise l'androstènediol comme substrat; l'intensité de la réaction est par contre très faible dans les 2 autres zones des surrénales d'intersexuées comparativement à celle des chèvres normales.

On a démontré que, dans les 3 zones corticales de toutes les chèvres normales, les enzymes surrénaliens ont la capacité d'utiliser la pregnénolone comme substrat bien que cette réaction soit plus diffuse chez les adultes tandis que chez les intersexuées et les chevreaux la réaction est localisée à la jonction de la zone glomérulaire et de la zone fasciculée.

On ne peut mettre en évidence la présence de $17 \beta$-hydroxystéroïde déhydrogénase ni en utilisant de l'estradiol, ni de la testostérone comme substrat chez les intersexuées et les mâles normaux adultes. Par contre, on peut détecter des traces de cet enzyme dans le cortex surrénalien des chevreaux, en utilisant la testostérone comme substrat et on obtient une réaction similaire mais faible avec de l'estradiol comme substrat, au niveau des zones internes des femelles. On s'aperçoit que la distribution de la $3 \beta$-hydroxystéroïde déhydrogénase dans les cellules de Leydig est faible chez les chèvres mâles et les intersexuées si on utilise l'androstènediol comme substrat.

Dans des expériences similaires, en utilisant la prégnolone comme substrat, on note une réaction positive faible dans les cellules de Leydig des intersexuées et dans le stroma des femelles adultes, mais la réaction est négative chez les mâles adultes et les chevreaux. Comme dans les surrénales, on ne peut déceler la 17ß-hydroxystéroïde déhydrogénase dans les testicules, ni avec la testostérone, ni avec l'estradiol comme substrats.

L'hypoplasie marquée et les dommages cellulaires affectant le cortex surrénalien des intersexuées et la très proche ressemblance avec les chevreaux pour la distribution des hydroxystéroïdes déhydrogénases ont été considérés comme une indication d'une interférence généralisée entre leurs cellules productrices d'hormones stéroïdes. 


\section{ACKNOWLEDGEMENTS}

This investigation was supported in part by a research grant from the National Research Council of Canada. The authors are indebted to Mr. A.K. Sykes and Mrs. Dorothy G. Friedman for efficient technical help.

\section{REFERENCES}

AlleN J.M., I960. A histochemical study of $3^{\beta}$-sterol dehydrogenase in the adrenal cortex of the developing mouse. Anat. Rec., 137, 57-63.

BAILLIE A.H., GRIFFITHS K., I964 a. 3 B-hydroxysteroid dehydrogenase activity in the mouse I,eydig cell. J. Endocr., 29, 9-17.

BAILlIE A.H., GRIFFITHS K., I $964 b . \quad 3 \beta$-hydroxysteroid dehydrogenase in the fetal mouse Leydig ccll. J. Endocr., 31, 63-66.

BAIllre A.H., GRIFFITHS K., I965. Further observations on $3 \beta$-hydroxysteroid dehydrogenase activity in the mouse Leydig cell. J. Endocr., 31, 207-215.

Baillie A.H., Cammeron E.H.D., Griffiths K., Hart D. McK., I965. 3 -hydroxysteroid dehydrogenase in the adrenal gland and placenta. J. Endocr., 31, 227-233.

BASrur P.K., Coubrough R.I., r964. Anatomical and cytological sex of a Saanen goat. Cytogenetics, 3, 4 I 4-426.

BaSRUR P.K., Kanagawa H., 1968. Cytogenetic studies on intersex goats. I3th meeting of the Genet. Soc. of Canada, Winnipeg.

BASRUR P.K., Kanagawa H. I969. Anatomic and cytogenetic studies on I9 hovnless goats with sexual disorders. Ann. Génét. Sél. Anim. 1, 349-378.

BAYER K.F., SAMUELS I.., r956. Distribution of steroid $3 \beta$-ol-dehydrogenase in cellular structures of the adrenal gland. J. biol. Chem., 219, 69-76.

BLANChETTE E.F., 1966. The fine structure of the endoplasmic reticulum of leutinized ovarian cells and isolated microsomes in relation to $\Delta^{5}-3 \beta$-hydroxysteroid dehydrogenase activity. Anat. Rec., 154, 3 I 8 (Abst.).

Brandau H., Remmlinger K., LuH W., I967. Enzyme patterns and progesterone synthesis. A histochemical analysis of the distribution of enzymes in the granulosa cells of the rabbit ovary before and after follicular rupture. Acta Endocr., 56, 433-444.

Chester-Jones I., 1957. The adrenal cortex. Cambridge University Press.

Davies J., DAVenport G.R., NorRis J.L., RENnie P.I.C., 1966. Histochemical studies of hydroxysteroid dehydrogenases activity in mammalian reproductive tissues. Endocrinology, 78, 667-67r.

Dawson I.M.P., Pryse-Davies J., SNape I.M., I96r. The histochemical demonstration of steroid $3 \beta$-ol dehydrogenase and diphospho-pyridine nucleotide diaphorase in the adrenal cortex. Biochem. J., 78, I6 (Abstr).

EWALd W., Werbier H., ChaikofF I.I., r964. Evidence for two substrate specific $\Delta^{5}-3$-ketosteroid isomerases in beef adrenal glands and their separation from $3 \beta$-hydroxysteroid dehydrogenase. Biochem. Biophys. Acta, 81, 199-201.

GARM O., I949. Investigation of cystic ovarian degeneration in the cow with special regard to etiology and pathogenesis. Cornell Veter., 39, 39-52.

GoldberG B., JoNes G.E.S., BorkowF H.I., I 964 . Histochemical study of substrate specificity for the steroid $3 \beta$-ol-dehydrogenase and isomerase systems in human ovary and testis. J. Histochem. Cytochem., 12, $880-889$.

Hamerton J.L., Dickson J.M., Pollard C.E., Grieves S.A., Short R.V., r969. Genetic intersexuality in goats. J. Reprod. Fert., Suppl., 7, 25-5I.

Hughes W., r929. The freemartin condition in swine. Anat. Rec., 41, 213-245.

ILBERY P.L., WILLIAMS D., 1967. Evidence of the freemartin condition in the goat. Cytogenetics, 6, $271-285$.

Jost A., I955. Modalities in the action of gonadal and gonad stimulating hormones in the fœetus. Mem. Soc. Endocr., 4, 237.

Jost A., I967. Steroids and sex differentiation of the mammalian foetus. Proc. 2nd int. Congr. Hormonal Steroids, Milan, 1966. Excerpta Medica, Int. Congr. Ser., 132, 74. Amsterdam.

KoImE S.S., MrTsuDo., r965. Histochemical study of $3 \beta$ and $17 \beta$-hydroxysteroid dehydrogenase in human term placenta. Endocrinology, 76, 403-407.

Korrtz S.B., I964. The conversion of pregnenolone to progesterone by small particles from rat adrenal. Biochemistry, 3, 1098-I 102. 
LIILIE F.R., 19I7. The freemartin; a study of the action of sex hormones in the fotal life of cattle. J. exp. Zool., 23, 371 .

MAEIR D.M., I965. Species variation in testicular $\Delta^{5}-3 \beta$ hydroxysteroid dehydrogenase activity : Absence of activity in primate L,eydig cells. Endocrinology, 76, 463-469.

Orno S., 1967. Sex chromosomes and sex-linked genes. Springer-Verlag, Berlin, Heidelberg, New York.

OVERzIER C., r963. Intersexuality. Academic Press, London.

Padeh B., Wysoki M., Ayalon N., Soller M., 1965. An XX/XY Hermaphrodite in the goat. Israel J. med. Sci., 1, Io08-1012.

Rubin B.I., Deane H.W., Hamilton J.A., r963. Biochemical and histochemical studies on $\Delta^{5}-3 \beta-$ hydroxysteroid dehydrogenase activity in adrenal glands and ovaries of diverse mammals. Endocrinology, 73, 748-763.

Samuels L.T., Helmreich M.L., Lasater M.B., Reich H., i95 I. An enzyme in endocrine tissues which oxidizes $\Delta^{5}-3$-hydroxysteroids to $\alpha \beta$-unsaturated ketones. Science, 113, 490-49r.

Schor N.W., GLICK D., I967. Determination of $3 \beta$-hydroxysteroid dehydrogenase system in microgram samples of tissue, quantitative histologic distribution of the enzyme in the rat adrenal and effects of adrenocoriticotropsin. J. Histochem. Cytochem., 15, r66-r7r.

Short R.V., Hamerton J.L., Grieves S.A., Pollard C.E., r968. An intersex goat with a bilaterally asymmetrical reproductive tract. J. Reprod. Fert., 16, 283.

Soller M., Padeh B., Wysokr M., Ayalon N., ig69. Cytogenetic of Saanen goats showing abnormal development of reproductive tract associated with the dominant gene for polledness. Cytogenetics, 8, 5 I-67.

WATtenberg L., r958. Microscopic histochemical demonstration of steroid 3-beta-ol-dehydrogenase in tissue sections. J. Histochem. Cytochem., 6, 225-232.

WIDMAIER R., I959. Nebennierenrindenknotchen in Nekenhodenkopf bei Ziegenbocken. Zbl. Vet. Med., 368, quoted by Koch W., in Intersexuality in mammals, Ed. Overzier, C. Academic Press. I963, pp. $35-47$.

ZANDER J., HenNing H.D., 1963. Hormones and intersexuality. In Intersexuality, Ed. Overzier, Academic Press, New York. 